\title{
Identity of the Vietnamese narrative culture: archetypal journeys from folk narratives to fantasy short stories
}

Nguyen Thi Kim Ngan (i] ${ }^{1 凶}$, Nguyen Thi Thu Hang ${ }^{1}$ \& Le Van Trung ${ }^{2}$

The journey to another world is an archetype that exists in the forms of marvelous motifs and is also a typical narrative formula with the purpose of creating diverse versions of Vietnamese folk narratives. The archetypal journey was later reborn and expanded in medieval literature as Vietnamese culture, which has become more complex over time. With the aim of discovering the cultural identity of Vietnamese narratives using sociohistorical approaches and discussing the archetype grounded in specific contexts, this research focuses on journey motifs to the upper and lower world in folk narratives in early collections written in Han characters and in related historical and cultural bibliographies. At the same time, by analyzing the fantasy short stories in Excursive Notes on Weird Stories (Truyen ky man luc) by Nguyen $\mathrm{Du}$, this study aims to discover the process of acculturation and creation of materials and motifs from folk narratives, and it discusses how these motifs have been adapted. This research reveals specific messages about the history, culture, era, voice and true identity of the medieval Vietnamese Confucian. Importantly, this study emphasizes the unification of spiritual power between folklore and Taoism and the powerful and influential competition between Taoism and Confucianism in medieval Vietnamese literature. The analysis shows that by recreating the motifs of the folk narratives, writers have built other world journeys to describe the hidden political discourses and religious conflicts in the thoughts of the human mind in the most ideal form.

\footnotetext{
${ }^{1}$ Department of Literature and Linguistics, University of Education, Hue University, Hue, Vietnam. ${ }^{2}$ Faculty of Primary Education, University of Science and

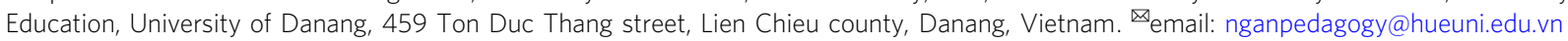




\section{Confucian writers and fantasy short stories in context}

rom the 10th century $\mathrm{AD}$ under the Ly Dynasty (1009-1225), the Vietnamese gained their independence after a millennium of Chinese domination (207 BC 938)

(Dao, 2016; Ngo et al., 2009). From this point in time, a model of totalitarian monarchy and centralized government from the Chinese pattern was chosen to address the country's urgent problems. Despite promoting Buddhism, Confucianism with the objective of "rule the country" in its doctrine was a perfect governing instrument for the state and completely adapted to government to create a world with a closed mainstream model in the vision of the Ly court at that time.

Confucianism began to flourish in Vietnam in the feudal era in the early Le Dynasty (Ngo et al., 2009; Nguyen, 1992), and the Vietnamese state had an urgent need for organization and management of the country according to a strict model. By the second half of the 15th century, the monopoly of Confucianism as the dominant ideology was strong during the reign of Le Thanh Tong (1460-1497) (Tran, 1999; Dao, 2016). The deliberate selection of Confucianism was intended to increase and consolidate the status of the ruling dynasty, which caused Taoism and Buddhism, which had come to Vietnam before the Common Era (Ngo et al., 2009) and had a considerable influence on the cultural figure of Vietnam, to gradually extend beyond the central area and become peripheral voices. To this time, Confucianism had surpassed the social components used in the past by Buddhist clergy who had become the monopolizing elites of society.

Although the Vietnamese feudal dynasties pursued nationalism and resolutely fought against the expansion of Chinese feudal powers, the choice of the Confucian intellectual model to dominate ambassadors' political paradigms and the use of Han characters as the official language created intricately dualistic cultural discourses in the history of Vietnamese thought. Literature from the $10^{\text {th }}$ century to the end of the 19th century as the creative genre mainly of Confucian writers also reflected the conflict and this tacit complexity. In the new period of literary formation from the 10th to the 15th centuries, the writings of Confucian authors in terms of themes and content all mentioned political culture with ideal social models based on a policy called "ruled by virtue" (đức trị) (Nguyen, 2000; Bui, 1999). However, in the period of violent and bloody wars and the rapid change in Vietnamese dynasties in the 16th and 17th centuries, Confucianism in Confucian writing presented a clear contradiction: helplessness before the breakdown of the political battle. The creation and integration of folk cultural materials and Taoist thought in the writings of Confucians, especially in mainstream prose narratives, with the typical genre called "fantasy short story" (truyen ky), showed a hidden link with the authors' attitudes of defying authority in the turbulent context of this period.

The historical context in which truyen $k y$ writers lived was an era of many wars among feudal groups mixed with a war against aggression. After the reign of King Tran Thanh Tong (1258-1278), the Le dynasty (1428-1527) fell into turmoil when six Le kings were successively killed or were otherwise incapable of ruling. The Le dynasty's weakness and crisis led to the rise of and usurpation by the Mac dynasty (1594-1677). However, the Trinh Feudal Lord supported the Le dynasty, defeating the Mac dynasty and ascending to the throne. Later, this family overwhelmed the power and turned King Le into a puppet. All events of these internal conflicts, division of territories and conflicts between the ruling class and the people that lasted throughout the 16 th and 17 th centuries. In particular, peasant rebellions broke out continuously in many places, Than Duy Nhac stirred up troops in Kinh Bac (1511), Nguyen Nghiem rebelled in Hung Hoa (1512), and the Tran Dao uprising occurred in 1516 (Ngo et al., 2009; Le, 2013; Dao, 2016).
Thus, political turmoil and war between feudal and enemy groups within foreign enemies became a part of Vietnamese medieval history. All these events eventually engendered clear changes in the spiritual life of the society. Faced with such a reality, Confucianism-a theory useful in peacetime-displayed powerlessness and was no longer attractive. In addition, from this important pivotal period, the fantasy short stories of Confucians appeared to be symbols of a tendency to return to the core values of a national culture.

Beginning in the 14th century, Vietnamese fantasy short stories in medieval times, also known as truyen $k y$ stories, originated from the Chinese chuanqi genre (Tran, 1995; Tran, 2000). This genre often borrows stories from folk narratives, exploits preexisting motifs, themes and plots from the world of traditional storytelling, and uses fantasy as an artistic means to convey problems with deep content relating to contemporary sociocultural life. Therefore, the connotation of truyen $k y$ is often emphasized in the phrase "phi ky bat truyen" (implying the preference for the transmission of strange stories in the human world). These stories are often characterized by coincidence, grandiose and sublime events reflecting the chaos and dissolution in real life (Lu, 1993). One of the genre's other key artistic features is that,despite being geared towards exposing political and social messages, the wording of fantasy short stories is sumptuous and elegant, with expressive ideas and romantic and rich details to create a mixture of prose and poetry. In particular, with the author's own ethical commentary at the end of the story, this genre often creates harmony and tension among strange events through genuine emotions and gives the reader a sense of ambiguity and insecurity about the metaphysical elements dominating his or her stage of life.

The birth of the fantasy story and its rapid development in the 16 th and 17th centuries was the result of the perfect artistic fusion of an exotic literary genre and endogenous flow of folk narratives. The materials of traditional folk stories in this genre seemed to have a quality that was easily recognized by readers. In the most famous collection including 19 fantasy short stories that are "reaching to the paradigmatic level", Nguyen Du's Excursive Notes on Weird Stories, many plots and motifs in the first folk narrative collections reappear. These folk narratives collections such as Spiritual Powers in the Viet Realm (Viet dien $u$ linh) by Ly Te Xuyen and Strange Stories Gathered from the Linh Nam Realm (Linh Nam chich quai) by Tran The Phap in the 14th century were written in Chinese characters by Confucian mandarins who recorded folk narratives at the request of the court.

Excursive Notes on Weird Stories, which is the only work of the famous Confucian Nguyen Du (a writer living in the 16th century; his exact birth and death dates are unknown), is considered the brilliant climax of Vietnamese fantasy short stories. Le Quy Don, a famous 17th century scientist, stated in Accounts on Things Learnt (Kien Van Tieu Luc) that: "Du from a young age was famous for learning widely, remembered a lot, and could use literature to make a great career. Many times, Nguyen Du won contests to pass the Confucian examination and was appointed chief of the Thanh Tuyen district, but only a year later, he used the excuse of working far away and being asked to take care of his parents. After the Mac Family took the throne, he vowed not to work as a mandarin anymore. The contemporaries of the continental record have four volumes, poetic language, and contemporary people extensively praise them (Le, 2013). The titles of the 19 stories in Excursive Notes on Weird Stories contain the words "ky", "truyen", or "luc". These words all have the common meaning of "records" (ghi chep). From the perspective of Confucius' humble language and artistic manner, these words indicate that the author regards his work as a collection of tales derived from folklore. 
With the aim of discovering the cultural identity of Vietnamese narratives with sociohistorical approaches and discussing the archetype grounded in specific contexts, this research focuses on journey motifs to the upper and lower world in collections of folk narratives written in Han characters in the 13th century and relates historical and cultural documents. At the same time, by analyzing the fantasy short stories in Nguyen Du's Excursive Notes on Weird Stories, this paper aims to discover the process of acculturation and creation of materials and motifs from folk narratives and discusses how the motifs are adapted, thereby revealing specific messages about the history, culture, era, voice and true identity of the Vietnamese Confucian.

\section{Regeneration of the archetypal journey: comparative analysis of Vietnamese folk narratives and literature}

As a country with a long-standing wet rice agricultural civilization more than 4000 years ago (Tran, 2006; Dao, 2016), animism and polytheism strongly influence the minds of Vietnamese communities, including a strong belief in the power of sacred mountains and the mountain gods living on top of host mountains. The belief in worshiping mountain gods is evident along the Red River delta and extends to neighboring plains in the North of Vietnam, where residents have suffered from the devastating impacts of flood disasters for thousands of generations (Vo and Ngo, 1990; Ta, 2006). This belief partly reflects the desire of people in wet rice farming to overcome and tame floods. Therefore, in the minds of the Vietnamese people, images of mountain deities together with sacred territories on the high mountains are both vividly present in traditional stories such as the series of Tan Vien Son Thanh, Chu Dong Tu, and have a strong presence in ritual practices in the temples of mountain gods around sacred mountains such as Ba Vi, Tam Diep, and Hoanh Son.

Stemming from this cultural feature, by researching the Vietnamese folk narratives in Spiritual Powers in the Viet Realm, Strange Stories Gathered from Linh Nam Realm and related historical documents, it can be seen that the journeys to paradise and hell are associated with the character setting foot on a sacred mountain and having strange encounters with the mountain god. Therefore, the symbol of the mountain is envisaged as a magical realm where the convergence of the sacred air of heaven and earth is the gateway to the magical heavenly world of the gods.

The Legend of Tu Thuc Cave (Su tich dong Tu Thuc) is the title of a folk narrative widely circulated in medieval Vietnam and is closely associated with the scenic Tu Thuc Cave located on the majestic Tam Diep mountain range bordering the Kim Son district in the Ninh Binh province. The place is known as the most beautiful mountain range and cave in Thanh Hoa land and is associated with the legend of the love of $\mathrm{Tu}$ Thuc and Giang Huong. In addition to the work of Tu Thu Married a Fairy (Tu Thuc gap tien), which was re-created by Nguyen Du in Excursive Notes on Weird Stories, this story was also briefly recorded by the anonymous writer in Copying from Strange Things Heard (Thinh van di luc) in the 17th century (Tran et al., 1997a) and through the part of the Sage worshiping at Hoanh Son mountain in the Vietnamese-Han script titled Vietnamese Taoist Legend ( $\mathrm{Hoi}$ Chan Bien) by Thanh Hoa Tu (Chan et al., 1992). "Classic reference" (Dien tich) Tu Thuc Giang Huong is also widely popular in other famous 17th century collections of fantasy stories such as a Strange Meeting in Bich Cau (Bich Cau ky ngo) by Doan Thi Diem (Tran et al., 1997a). The legend of this magnificent melancholic love is also the inspiration for the poem Du Phat Tich Ngau De Son by Pham Su Manh, who lived in the 14th century, and Le Quy Don's poem De Tu Thuc Dong composed in the $18^{\text {th }}$ century. The Legend of Tu Thuc Cave is a folk narrative that was popular and widely circulated in folklore before becoming the inspiration for medieval writers.

In the story, Tu Thuc is mentioned as a famous Confucian who lived under the Tran dynasty (1225-1400) and as a mandarin in Bac Ninh. He is known as an intelligent, benevolent ruler who enjoys rambling about natural scenery and writing poetry. Adjacent to the district, there is a famous pagoda where flowerviewing festivals are held and where many horse-drawn carriages add to the bustle. Under the peony tree is a beautiful young woman with her hand resting on a branch. The flower suddenly breaks apart, and then, the girl is punished by the temple keeper. $\mathrm{Tu}$ Thuc passed by, and he took off the brocade cloak he was wearing to rescue her. After leaving his office early, Tu Thuc, who enjoyed traveling mountains and rivers, went on an excursion to Hoanh Son mountain, passed Nga Son, and finally arrived at Bich Dao cave where there are steep cliffs. Tu Thuc thought of a poem and wrote it on the wall when the cave door opened, and a page led $\mathrm{Tu}$ Thuc to enter the magical world on the mountain top. In the world of immortals, Tu Thuc married and lived happily with the fairy Giang Huong, who was the beautiful girl breaking the peony branch who he had helped during the annual flower festival. Soon, Tu Thuc also attained first enlightenment. However, after a year in the fairyland, Tu Thuc became disheartened and even wished to return to his own town. He was brought back to earth by his fairy wife in a mythical carriage. However, 100 years had passed since he had left his old place; only the rocky slot was the same, and everything else had changed completely. Then, Tu Thuc traveled to Hoanh Son Mountain again, and no one knew him anymore. Currently, people call him "Vu Khach Hoanh Son" (Hoanh Son Taoist), and Bich Dao cave is known as Tu Thuc Cave (Chan et al., 1992; VASS, 2004).

In the Tu Thuc Cave story, the nature of the upper world is not clearly depicted, but the time of the journey has strange features. Time travel involves crossing disparate worlds to explore the space realms of the universe. The one-sided story shows the aspirations of the folk people in discovering the existence of many worlds expressing the dream of a love affair through time. On the other hand, the story conveys the contrast between foresight and earthly time, highlighting the fragile and fanciful feeling of an eternal world of which people dream.

within addition to the legend of Tu Thuc Cave, the Chu Dong $\mathrm{Tu}$ story, another typical legend about one of the four important and immortal gods in the mind of the Vietnamese was recorded in the book Viet Dien U Linh in 1329 (Ly, 1961). This story also features an archetypal journey with the motif of enlightenment into a God and magic on the high mountains. Therefore, the mountain in the folk belief of worshiping mountain gods becomes a symbol of the gate to heaven, the place of reincarnation, and the immortal for the gods in Taoism. In the spirit of seclusion, adventurousness, and the journey to the upper world of Tu Thuc, the Chu Dong Tu bears the Taoism color. Then, Taoism, especially Taoists, soon merged into the local folk beliefs and into the spiritual life bearing the metaphysical color of the Vietnamese people. (Vu, 2017; Nguyen, 2018)

Re-created by Nguyen Du based on the widely circulated story about the legend of Tu Thuc Cave in folklife, the story of Tu Thu Married a Fairy in Nguyen Du's Excursive Notes on Weird Stories is considered one of the most magnificent time travel stories in medieval Vietnamese literature. In the preface written in 1547 for Excursive Notes on Weird Stories, a famous Confucian who lived at the same time as Nguyen Du, Ha Thien Han, said that the author created this collection during a time when he resigned and returned the homeland by "taking care of the old mother" and then secluded himself in the forests of the Thanh Hoa realm (Bui, 1999), which may be why the legends of the Sage, Taoist, and Gods, including Tu Thuc, were worshiped in the 
temples in this land and were the first stories rewritten by Nguyen Du. In Tu Thu Married a Fairy, Nguyen Du describes Tu Thuc as a typical Confucian who chose "the Wu-Wei principle" (vô vi) by becoming a hermit and being at one with the Tao.

"Unable to force himself in fame, Tu wants to return his seal, leaves the mandarin to return. He loves the cave scene in Tong Son, so he built a house there to stay. Often using a page to bring a gourd of wine and a woodwind flute with him, he recites some poems by Dao Uyen Minh. Wherever he likes, he falls down to drink wine" (Tran et al., 1997a p. 243)

The story also describes in great detail Tu Thuc's journey to the fairyland on the top of the mountain, the meeting with the ruler god of Nam Nhac mountain, and the conversation mixed with poetic improvisations to express his open-mindedness and $\mathrm{Tu}$ Thuc's aspiration to find a utopian society:

"Up to the mountain, it will be bright. All around the magnificent castles, red green clouds clinging to the railing, exotic flowers bloom in front of the door. Tu thinks that if it is not a magical temple of god, it is all the territory of sage, grotto paradises. Then suddenly he saw two fairies in blue said to each other:

\section{- Our groom has just come!}

Right after that, they rushed inside to report the news, and after a while they went out and said:

- Our lady invited you to come in.

Tu followed them, circled around a brocade wall, entered a golden door and saw silver palaces standing in front of them with signs "The Delusional Temple”, “The Integrative Light Castle". Upstairs he saw a fairy in white sitting on a bed where there was a small sandalwood guitar. She said that:

- Your curiosity has become experienced. The joy in this outing is also satisfying your aspiration. But do you still remember the predestined relationship?

Tu said that:

- I am a recluse in Tong Son. I only have a wind sail, a bamboo boat, and travel to anywhere I like to live. However, I still do not understand what you meant, but dare to ask for clear instructions.

The fairy smiled and said:

- Well, it seems to be hard for you to understand. This is Phu Lai Mountain, the sixth of 36 caves floating in the clouds, wind and over the sea, like two La Phu Mountains dissolving in the wind and rain, like Elysium stretching with ripples. And I, the nymph of Nam Nhac Mountain, am Nguy's Lord. Because I see you as a noble person willing to help people in need, so I dare to bother inviting you here" (Tran N. et al., p. 245).

Although almost re-using the plot of the legend of Tu Thuc Cave, the folk narratives express the idea of the coexistence of many worlds, emphasize the journey through time, and show the desire to freely seek love. The journey to the upper world in Nguyen Du's Tu Thu Married a Fairy has political influences intertwined with the issue of ideological and religious conflict through a lyrical, beautiful, and poetic narrative language. The full description of the process of Confucian $T u$ Thuc when hanging the seal from the mandarin and the discourse about "escaping" to the utopian society on the high mountains to become a Taoist are implied to explain the cause of the transformation and the political doctrine of the contemporary Confucians and highlight the helpless tragedy in the midst of the vast world of $T u$ Thuc.

"He only walked for a moment and came home but saw things changed. In details, the world landscape was no longer the same, only the ravine scene did not change the blue color of the past. Tu Thuc then took his name to ask the old people and found a person who said that:

- In my childhood, I heard there was an old man in my village told that your name is similar with my greatgrandfather's surname. It has been nearly a hundred years since he entered the mountain, it was from that time of the 5th year (1458) of the Dien Ninh period, the third king's life of the Le Dynasty.

Sadly, he felt like he wanted to get back on the cloud truck to return to the heavenly world, but the cloud carriage had turned into a bird flying away. Opening the letter of Giang Huong, there was a sentence: 'The phoenix's marriage promise is in the clouds, the old karma has ended; looking for a fairy mountain in the ocean that occasion no longer exists'. Tu Thuc did not realize a truth that his fairy wife had mentioned the last farewell to him before. Then, he wore a light sheepskin, a short conical hat, and went forever to Hoanh Son mountain" (Tran et al., 1997b).

Thus, the adaptation of the journey motif to the upper world in the fantasy shows that Confucian writers under the hidden influence of folklore and Taoism found "the Way and the Power of the Way" to create the transcendent connection between humans, the universe and Dao. This transformation had the effect of replenishing the lacking Confucianism metaphysical vision, a rational theory that Confucianism could not carry out. On the other hand, the need to revive the journey archetype in 16th and 17 th century fantasy literature also symbolized the desire to find a utopian society, reflecting "rebellious" discourse and the need for liberation from the present deadlock of Confucianism. Therefore, despite recreating folk narratives, the complex political and religious implications interwoven in a nostalgic love story allowed the story of Tu Thu Married a Fairy to have a strong diffuse effect on the intellectual community and the folk at that time. Commenting on the wonderful impact that Tu Thu Married a Fairy had on the widespread circulation of folk narratives, with the legend of $\mathrm{Tu}$ Thuc Cave, Chinese researcher Tran Ich Nguyen stated that

"It is possible that Tu Thuc and Giang Huong are legendary figures that existed in the Nguyen Du period. After being put in the story of Tu Thu Married a Fairy, it was even more widely spread and eventually deified by the Taoist clergy. Excursive Notes on Weird Stories, in terms of influencing folklore, has such a great influence. It is a surprise" (Tran, 2000).

The Woodcutter of Nua Mountain (Nguoi tieu phu nui Nua) is another story in Excursive Notes on Weird Stories and describes the typical journey to the upper world on the high mountains of folk narratives, but the motif references fully expressed the particular cultural and social problems and historical theme of Vietnam in the 16th and 17th centuries. This story was written in Han characters in the form of short prose mixed with poetry, and 
the story ended with the author's own commentary. Similar to many other plots in the story collection of Nguyen Du, in the story the Woodcutter of Nua Mountain, the author also borrowed a character that was praised by the world in the traditional story and then reorganized the character structure, adding details and editing words to create a new story.

The Nua mountain forest area in Thanh Hoa, the context of the story of the Woodcutter of Nua Mountain, remains an Am Tien relic worshiping Taoist. Folk believe that this place has a yang and that all the aura of heaven and earth will be gathered at this holy point. Some historical bibliographies and important autobiographies such as Du Dia Chi in the 15th century by Nguyen Trai (2019) and Vietnamese Historical Geography (Dai Nam Nhat Thong Chi) in the 19th century (NHIND, 2006) mentioned the sacred mountain $\mathrm{Na}$ and the legend of the woodcutter hermit. These documents described that the old character of Mount Nua as a real person. His surname is Tran, his real name is $\mathrm{Tu}$, and people contemporarily called him Uncle $\mathrm{Tu}$ Nua. Because of the turmoil of the Tran dynasty, he set up a thatched tent to stay hidden. Therefore, based on factors such as Nguyen Du's hidden background in the sacred mountainous region of Thanh Hoa, the Am Tien relic of Taoist worship on Nua Mountain remains in the tradition of worshiping the mountain gods of folk beliefs, and the top of the mountain is the convergence of heaven and earth, as well as the residence of the gods. Nguyen Du can be said to have absorbed material folklore to write about contemporary semi-fictional Taoists and the motifs of the journey to the upper world of the traditional narrative and conveyed his important political messages.

"On a hunting trip, Ho Han Thuong (the last king of the Ho Dynasty 1400-1407) strayed into the fantasy world in Nua Mountain and met a strange hermit. Ho Han Thuong accidentally heard from this stranger hermit three poems with many different implications. The first poem is meant to express the thought of living outside the canonical rule of the social community to bind people and the desire to live completely with the wu-wei principle. The second one is entitled Fond of Sleeping (Thich $n g u$ ) and the third one titled Fond of Chess (Thich co) on the wall implying two dialectical conflicts of Living "static" (in Fond of Sleeping) and "dynamic" (in Fond of Chess). (Tran et al., 1997b).

Truong Cong, an officer in the entourage, was ordered to accompany the hermit to meet Ho Han Thuong, but Truong Cong followed close to the place and saw that he entered the cave quickly; then, he called that person but received no answer, only "saw that person riding clouds, walking freely in a moment of pineapple branches”. Following the faint footsteps of the Taoist, Truong Cong plunged into magical space and time in the high mountains. All night long, the hermit was talking and listening to the main discussions, predicting the fortune of the strange woodcutter. Although Truong Cong tried to persuade the hermit to bring talent to serve the dynasty, the woodcutter hermit refused.

After a while, the officer Truong Cong returned to the old mountain temple and hoped that the strange hermit would help the nation again. However, he only saw the scenery of "moss covering the cave entrance, thorns overgrown in the mountains with vines, and bushes filling the path". He saw only two traces of verses written in tree sap on the cliff: "Ky La seaport is where the spirit will be ruined. Cao Vong mountain is where a traveler's sentiment reaches to upset". The implication of these two verses is a prediction of the fall of the Ho Dynasty shortly after, which is why Ho Han Thuong angrily ordered the burning of the mountain upon hearing this predictive poem. The mountain was burned down, but a black crane was found flying in the air. Later, exactly as predicted in two verses, the Ho dynasty met disaster. Ho Quy Ly was captured at the Ky La seaport, and Ho Han Thuong was defeated at Cao Vong mountain by the Chinese Minh army. That time was also a mark of the decline of the Ho Dynasty.

The story of the Woodcutter of Nua Mountain created a typical allegory of medieval literature that clearly shows the tendency to prefer the mysticism and ideology of Confucian intellectuals in Tran Ho times and Vietnamese Taoist colors. This spirit reflects the fact that medieval Vietnamese Confucians and writers were the product of Confucian training, but in times of turmoil, most of them chose the hidden spirit of Taoism. This image of high mountain hermitages clearly reveals the pessimism and the inadequacy of not finding a way out on the writers' journey to practice Confucianism.

Thus, the spirit of the transformation from Confucianism to Taoism among reclusive Confucians such as the Woodcutter of Nua Mountain or Tu Thuc showed that in the 16th and 17th centuries, the Confucian orthodoxy captured the human heart. This peacetime doctrine has shown its powerlessness in the face of the breakdown of the political matrix and bloody violence. Confucians then sought out and expanded the system of thought as a necessary adjustment to reconcile with reality. Taoism is a religion that is closely intertwined with the Vietnamese folklore background chosen by the Confucians, which also shows that, in the fantasy story, although positively inheriting the materials from folk narratives, the motifs were clearly and completely used to convey cultural problems and typical the politics of contemporary society.

While the journey to the upper world was upright and full of light, the archetypal journey to hell was a symbol of the journey of regression, backsliding and deep into the world of darkness (Aldridge et al., 1988; Garry and Hasan, 2005). Images of the hell world developed very early in the beliefs, customs, and folk festivals of Vietnam under the universal influence of the polytheism beliefs, the yin-yang doctrine of the wet rice agricultural civilization and the influence of Buddhism introduced into Vietnam before the Common Era (Nguyen, 2018; Ta, 2006).

In Vietnamese folk narratives, the most prominent journey to the underworld is described in the story titled Thu Huong with the typical motif of "going to the dead land to visit the dead" (Thompson, 1958) and the Vietnamese motif of the yin-yang market. The story is about a man who lost his wife very early. When he was a mandarin, he leveraged extensive injustice for his own benefit. In the later years of his life, when he was alone without children, he decided to find the yin-yang market, which was a bizarre market that took place only once a year and was known as a place where transactions regularly occurred between the dead and the living, and for a few special moments of yin-yang harmony, he accidentally encountered his dead wife there. The wife took Thu Huong to visit the lower world where he met the god governing the nine layers of hell, saw countless small rooms that held prisoners, and witnessed his fierce punishment in the next life. Upon wakening, Thu Huong hurried back to earth and began to give away all his inheritance. Historical documents indicate that he made friends and provided rice and money to the poor who stopped and waited until the river tide reached the junction of Gia Dinh River. Today, a temple named Thu Huong, which was built and worshiped by the people, is still standing at the confluence of this river (VASS, 2004; Le, 2015).

The Thu Huong story is considered a typical example of transitioning from the earth to hell through the yin-yang market. The ancient Vietnamese with a background of thinking that a static form of agricultural culture produced the negative/yin (the feminine principle of the universe) and positive/yang (the masculine principle of the universe) concept. These opposite ideas are 
considered to be two basic principles of the universe in mutual relation, thereby creating all dialectical phenomena in the universe, including the heaven and the hell world. In the story of Thu Huong, the details showing characteristic features of traditional Vietnamese culture include the gateway motif leading to hell and the motif of the yin-yang market where the living and the dead can meet and talk together. The yin-yang market is a longstanding cultural custom of indigenous people in the North from the Tran dynasty. These spiritual yin-yang markets are held only once a year at night and are also known as "the spiritual sessions". Thus, the Thu Huong story is one of the typical folktales showing the influence of Buddhism with the philosophy of karma and the cycle of the law of cause and effect on Vietnamese people's minds.

However, while depictions of the hell world have a strong presence in folk paintings such as Dong Ho, Trong and Sinh Village, in the practice of exorcisms, the July lunar month's amnesty or in funeral rites (Nguyen, 2018), otherworld journeys to the lower world in Vietnamese folk narratives collected in medieval times are quite limited. In contrast, this archetype thrived in medieval fantasy. In this archetype, we can easily realize that the journey to hell in the fantasy genre is much richer than the journey to heaven. Full depictions of hell with death and darkness related to karma have most likely appeared in Buddhist legends very early (Nguyen, 2014), but in fact, this metaphysical journey was developed and expressed with all its levels of meaning in the literature first in the medieval narrative. Confucian writers chose the hell archetype to entrust their metaphysical experiences of life, emphasizing the discourse of "helplessness" in resisting stereotypes and the oppression of Confucianism. Therefore, through the development from folk beliefs combined with the development of a new level of metaphysical philosophical thinking, the displacement of space to the hell world has become a symbol of dramatic conflicts about ideology in fantasy stories.

Basically, the classical structural model of the heroic archetype and the motif of the journey down to the hell world in mythology and folk narratives are fully preserved in the mysterious cycle of death and resurrection (Rank, 1914; Garry and Hasan, 2005) of characters in medieval fantasy short stories. However, this genre does not emphasize the strange fertility motifs. The fantasy characters do not even have a supernatural power such as the folk hero, but they have successfully completed the challenges and special tasks set out for the hero with the spirit of "the five constant virtues" of Confucianism. Therefore, when they die, they ascend to heaven and join the world of the gods. The story of the Chancellor at Tan Vien Temple (Chuc phan su den Tan Vien) is an example:

"Ngo Tu Van is from Yen Dung district, Lang Giang land. He was impatient, seeing the wickedness could not stand it, and there was a rumor from people in the North that he was a tough fellow. In the previous village there was a very spiritual shrine. At the end of the Ho dynasty, the Chinese army went to rob the area and became a battlefield. The Minister of Moc Thanh had an officer whose surname is Thoi, died in battle near the temple, and since then he has been a demon in folk. Tu Van was very angry, one day showered and washed, prayed to heaven and lit the temple. The people were all afraid for $\mathrm{Tu}$ Van, but $\mathrm{Tu}$ Van did not care” (Tran et al., 1997b).

Shortly after this "extravagant" act of Tu Van, a sudden illness struck. He was asked by the ghost of a Chinese officer who claimed to be a god of the temple to demand that the temple be returned. At night, his sickness became worse, and he saw two demons rushing to take and drag him out of the city to the east. Approximately one-half day was required to reach a large palace surrounded by a high iron wall with dozens of staff. Two demons reported to the ambassador of hell, and then, the ambassador came in for a time and commanded: "The crime is very heavy, so the crime sentence is not reduced. Saying so, waving his hand to go north, that is the great river. On the north river there is a bridge estimated to be more than a thousand steps long, the wind is greyish and a bit cold. On the two sides of the bridge, there are tens of thousands of demons, both blue eyes and red hair, the shape looks very evil" (Tran et al., 1997b).

At night at the court of justice in hell, Tu Van clarified the truth about a defeated Chinese General turned into a helpless ghost in Vietnam who argued to occupy the temple and disguised the blessing body to disturb the villagers. Subsequently, he was granted permission and returned home safely by the king of hell. The story ends with the following detail: "Tu Van returned to arrange housework, a few days later he was not sick but died. Behind this seemingly enigmatic death, it can be seen that there was a journey of Confucius following the call of the god, who invited him to carry out some lofty missions in the other realm and was ordained as the Chancellor at Tan Vien Temple. A worthy reward for the merits he has accumulated on earth"(Tran et al., 1997b).

Therefore, the seemingly sudden death, journey to the hell world, rebirth, and transformation into the god of Ngo Tu Van is a plot model to confer enjoyment from the life cycle of the hero in folklore. However, the color of the rite of sacrifices and the rite of passage in folk narratives have disappeared and completely replaced with the content of the new society based on the inspiration of "quan tu" (honoring gentlemen) and upholding the moral values according to the spirit of Confucianism. Importantly, all these new political, religious, socio-cultural contents readers do not seem to assume a story is strange from the title as the story has been associated with the temple of St. Tan Vien, which is the oldest temple in Vietnam built during Chinese domination (Ly, 1961; NHIND, 2006). The temple is intended for worship of one of the four dark deities of the Vietnamese people, and the legend of Tan Vien is recorded in Spiritual Powers in the Viet Realm. In addition, in the commentary of the end of the story, Nguyen Du emphasized: "Up to now, children and grandchildren still exist, they are said to be the Chancellors family" (Tran et al., 1997b). These common room-style endings clearly show the author's habit of recording old stories, tacitly emphasizing that the legend of the Tan Vien Temple is based on a local legend.

Clearly, Nguyen Du purposely chose mainly historical contexts for his stories at the end of the Tran Mat, Le and Ho dynasties, which were full of chaos and turmoil. In that context, the ubiquitous demons and human emotional tragedies are intimately linked with the constant warfare and corrupt contemporary politics. Borrowing from the past to refer to the present such as in this manner is a familiar feature in the literature with political implications. Through charming stories, demons and journeys to other utopian worlds, Nguyen Du discreetly expressed his deep dissatisfaction with the late Ho dynasty, and Nguy Mac also wanted to be strictly a threat to the Minh enemy from China, which is the reason why the legend of Van Di Thanh, who helped in King Tran Trung Quang's fight against Minh invaders in the early years of the 15th century, was borrowed by Nguyen Du to write the story of the Devil General (Tuong Da Xoa)

The story is related to Voi Phuc temple (built in 1420) in the Coi Son area. This temple worships Van Di Thanh (1380-1416) who recruited soldiers to organize insurgents against Minh invaders. Interestingly, the character Van Di Thanh hardly appeared in historical documents except at the Voi Phuc temple, and 40 King's texts of ordinations from the Le Dynasty in 1620 to the Nguyen Dynasty in 1924 bestowed Van Di Thanh with noble 
titles such as: "Vietnamese Supreme God" and "Vietnanese Hero". Due to the complexity of this history, Van Di Thanh along with the Voi Phuc temple have become the favorite characters of many legends. In addition, when entering the artistic world of Nguyen Du, Van Di Thanh in the story Devil General became the typical hero who took on the task of taming and controlling the world of ghosts.

The story describes that he was originally a scholar in Quoc Oai. At the end of Trung Quang's times, demons were present everywhere, people often died, and helpless souls gathered in large groups, raging in the countryside without fear of anything, but when they saw Van Di Thanh, they all ran away. After a journey to hell at the invitation of messenger Minh Ty and the recommendation of demons to find people "to authorize the management of the lives of the public and human beings", Van Di Thanh returned to earth and said: "If a man is born in life, they should know how to save his name forever, there is no reason to bow in the mundane world and to have fear of death" (Tran et al., 1997b). He arranged for the housework to be completed and died without becoming sick. The reality behind his seemingly sudden death is deification, canonization and the journey to another world to carry out the mission of controlling life according to the call of the gods.

In the structures of stories such as Devil General or Chancellor at Tan Vien Temple, the characters Ngo Tu Van and Van Di Thanh all left the real world and experienced strange adventures, including journeys to the hell world. The characters overcame challenges in the lower world, perceived great truths and completed the life cycle of the hero's death and rebirth. The story has also inherited some of the conflicts and basic patterns of folk narratives, such as difficult quests and/or the battle between good and evil, but clearly, new historical social messages predominate (Bottigheimer, 2009). By letting the characters adventure to the hell world, experience strange events, and practice the principle of "virtue"-a principle no longer applicable in the real worldwriters built other world journeys to describe the conflicts of thought in the human mind, between good and evil, and between order and disorder in the most ideal form. At the same time, with frequent recurrences and adaptations in the literature in the 16th and 17th centuries, the journey to hell motif is the clearest representation of the tragedies of thought and the failure of the Confucians to deal with reality.

\section{Archetypal journey from folk narratives to medieval literature: historical, political, cultural dynamics and creative art}

Although it was formed relatively late, the medieval literature of Vietnam still bears the same characteristics as the writing of other countries in the world started by recording folk literature. This process corresponds to the early period of medieval literature, which is the period from the 10th century to the 14th century. Authentic literature only truly appeared in the 15th century and made great advancements in the 16th and 17th centuries, the most prominent of which was the fantasy short story (Tran, 2014). The writers of the elite, those who were strictly trained by Confucian ideology under the influence of long culture, belief, and folklore traditions of the nation and influenced by the common religions of the Sinicized region, created this genre. However, the feature that distinguishes medieval Vietnamese short stories from Chinese stories, giving them a unique face and nuance, is the inheritance of the motifs and plots from Vietnamese folk narratives (Nguyen, 2000).

This process of transforming and re-creating this traditional narrative of a fantasy story can be explained from many different perspectives. The first important factor comes from the biography and parallel position of Confucian writers, of which Nguyen Du is a typical example. On the one hand, Confucians were political intellectuals, and their unique life and social class were intimately attached to the feudal state. On the other hand, most Vietnamese Confucians were from a peasant lineage. They grew up in traditional villages where community education was built on the foundations of the metaphysical folk belief and narratives of the wet rice farmers. Consequently, despite the success, mandate and advancement of Confucian examination, Confucian writers never seemed to give up their village roots (Tran, 2012). The ideology of the essence of Vietnamese folklore has been summarized through thousands of years flowing through the blood of writers. Thus, the Confucians' resistance to the crisis of society in the period of fierce and volatile history in the 16th and 17th centuries was critical.

One of the other important causes comes from the cultural, social and political characteristics of medieval Vietnam. At this stage, culture does not seem to be a field capable of becoming independent and distinct from politics. The Confucian, both a symbol of the political system and an intellectual, had the mission to "cultivate" people, and at the same time had the responsibility to expose political consciousness through the implied messages intertwined in the literature. Therefore, we are not at all surprised that political implications are always the first goal of the writers in the process of re-creating traditional folk cultural materials as literary works. The Confucians took advantage of all conditions of speech by composing literature to send messages to the emperor. The nineteen comments at the end of the story by author Nguyen $\mathrm{Du}$ in Excursive Notes on Weird Stories with the motto "raise the saint's bow, pluck the king's sword" and "encourage good to punish evil" are the most vivid proofs for this purpose.

Most importantly, when discussing the borrowing of traditional narrative materials from traditional tales the cause of the conflict and ideological competition of the prevailing religions in Vietnam at that time should be mentioned. The essence of Confucianism is a moral religion that only shows its usefulness in unifying the nation and all classes of society with a peacetime unification. However, the 16 th and $17^{\text {th }}$ centuries were the most violent period in Vietnamese history. The authoritarian feudal social model proved powerless in self-control, crisis in the face of civil war, enemy invasion from China and turmoil in the face of peasant rebellion. Confucianism now must determine and expand its own system of thought by itself. Taoism, an ideology with a close connection to Vietnamese folklore from before the common era was chosen by the Confucians to make a compromise with reality.

This implicit transition from Confucianism to Taoism of the writers has received strong support from the Vietnamese folklore background. In the context of losing its most important position, oppressed social status, and forced removal from dominant discourse, most Confucians chose to live in seclusion. They wrote the superficial tales that appeared to be out of this life, leaving the world (Nguyen, 2017). Their truths inside are discreetly expressed as belief, revealing the thought of noncooperation and the resistance against social reality. They practised collecting, writing, and telling mysteries in the peripheral world as a method to challenge the Confucian cultural and political powers at the center. Thus, the utopia of social aspirations in the writings of the Confucian writers offers a mixture of Confucian political visions at the surface of the text and the desire to understand the transcendent nature of the relationship between human and nature of Taoism and the folk metaphysical elements from the wet rice agricultural civilization tradition.

Notably, the tradition of the creation of Eastern art and esthetics has a strong impact on the phenomenon of "borrowing" folk narratives. The author is consciously educated and 
traditionally raised with ancient elements, faithful to the tradition and with admiration for the prestige of the previous Sages. "Classic reference" to the medieval writer always has a positive meaning, and what belongs to the "classical" era is an unattainable ideal standard. The main purpose of writers' creations is to capture the crystallized values of the old era and to simulate the perfect creative patterns that have shaped over time and thereby create a very ancient spirit. "I transmit but do not create. Being fond of the truth, I am admired of antiquity" is the motto of not only behavior but also an artist's composition. Since then, this approach to art has led to the importance of simulation over creativity and a preference for classical stories, preferring to borrow traditional plots rather than creating completely new standards.

\section{Conclusion}

Through archetypal journeys, the fantasy short stories of medieval Vietnam contributed to the successful construction of the metaphysical world at deeper levels in the literature and represented a breakthrough in the process of artistic transformation from the acquisition of religious ideas and the exploitation of the materials of folk narratives. The process of reconfiguring archetypes in Vietnamese medieval literature revealed complex issues related to the historical, social, and cultural context in the 16th and 17th centuries. Vietnamese medieval literature reflects the power and influence of the competition between Taoism and Confucianism and the conflict between the official Confucian discourse of dynasty and the unofficial, resistant discourse that strongly manifest in the Vietnamese culture with the unification of spiritual power between Folklore and Taoism.

As Valk (2005) argues in Discursive Shifts in Legends from Demonization to Fictionalization: "the complex relationship between often-fragmentary oral traditions and authorship as a synthesizing force in constructing neat and coherent narratives". Through the fantasy story genre, medieval Vietnamese writers demonstrated the ability to adapt folk materials and allow them to reach the highest artistic level by using an endless amount of natural and cultural energy in the motifs of folklore. At the same time, they absorbed, transformed and reproduced archetypes from folk narratives into artistic texts. Traditional folk narratives in this circumstance provided archetypes such as the story's nuclear narrative units and literature based on this archetype to present a new cultural, social and historical message. Hence, by exploring the rebirth of the archetypes, Vietnamese writers adapted to traditional folk narratives and harmoniously adapted the faiths and aspirations of their cultural background through special narrative techniques.

\section{Data availability}

All data generated or analyzed during this study are included in this published article.

Received: 2 July 2020; Accepted: 14 December 2020;

Published online: 13 January 2021

\section{References}

Aldridge O, Arnold A, Peter LH (1988) Dictionary of literary themes and motifs A-J. Greenwood Press, London

Bottigheimer R (2009) Fairy tales-a new history. Published by State University of New York Press, Albany

Bui DT (1999) Khao luan ve mot so tac gia, tac pham van hoc Viet Nam trung dai (Studies on some Authors and Literary Works of the Middle Age). Nha Xuat Ban Giao Duc, Ha Noi
Chan H-H, Trịnh AT, Tram N (1992) Viet Nam Han van tieu thuyet tung san (Collection of Vietnamese Novels Written in Han Characters) (tap 2). Hoc vien Vien Dong bac co, Ha Noi (5 vols)

Dao DA (2016) Dat nuoc Viet Nam qua cac doi (Vietnam through the Dynasties). Nha Xuat Ban Hong Duc, Ha Noi

Garry J, Hasan El-S (2005) Archetypes and motifs in folklore and literature: a handbook. M.E. Sharpe, New York

Le QD (eds) (2013) Kien van tieu luc (Accounts on Things Learnt), 3rd edn. (Trans: Le, TD). Nha Xua Ban Tre, Ha Noi (2 vols)

Le T (eds) (2013) An Nam chi luoc (Concise Historical Records of Annam), 3rd edn. Nha Xuat Ban Hong Duc, Ha Noi, (20 vols)

Le VL (eds) (2015) Bien Hoa su luoc (Brief history of Bien Hoa province). Nha Xuat Ban Tre, Ha Noi

Lu X (1993) So luoc lich su tieu thuyet Trung quoc (Brief History of Chinese Fiction) (Trans: Luong, DT). Nha Xuat Ban Van Hoa, Hanoi

Ly TX(eds) (1961) Viet dien u linh (Spiritual Powers in the Viet Realm), 8rd edn. Nha Xuat Ban Khai Tri, Sai Gon, Trans: Le, HM

National Historical Institute of Nguyen Dynasty (2006) Dai Nam nhat thong chi (Vietnamese Historical Geography), 3rd edn. Nha Xuat Thuan Hoa, Hue, (vols 5)

Ngo SL et al. (eds) (2009) Dai Viet su ki toan thu (Comprehensive History of the Great Viet) (Trans: Ha, VT). Nha Xuat Ban Van Hoc, Ha Noi

Nguyen DN (2000) Van xuoi tu su Viet nam thoi trung dai (Vietnamese narrative prose in medieval times). Nha Xuat Ban Giao Duc, Ha Noi

Nguyen DT (1992) Lich su tu tuong Viet Nam (History of Vietnamese Thought). Nha Xuat Ban Thanh Pho Ho Chi Minh, Ha Noi

Nguyen N (2002) Phien dich hoc lich su van hoa: Truong hop Truyen ky man luc (Historical and Cultural Translation: The Case of Truyen Ky Man Luc). Nha Xuat Ban Dai Hoc Quoc Gia Thanh Pho Ho Chi Minh

Nguyen L (2014) Viet Nam Phat giao su luan (The Essay of Vietnamese Historical Buddhism). Nha Xuat Ban Van Hoc, Hanoi

Nguyen N (2005) Jiandeng Xinhua and Truyên kỳ mạn lục: adaption as literary interpretation. Dissertation, Harvard University

Nguyen TKN (2017) Folklore and fantasy short stories in medieval literature of vietnam: otherworld journeys. Asia-Pacific Social Science Review 17 (1):112-120

Nguyen T (2019) Du dia chi (Geographical Records) (Trans: Phan, HT), 5rd edn. Nha Xuat Ban Dai Hoc Quoc Gia Ha Noi, Ha Noi

Nguyen VH (eds) (2018) Van minh Viet nam (Vietnamese Civilization). (Trans: Do, QT). Nha Xuat Ban Hoi Nha Van, Ha Noi

Rank O (1914) The myth of the birth of the hero: a psychological interpretation of mythology. The Journal of Nervous and Mental Disease Publishing Company, New York

Ta CĐT (2006) Than va nguoi dat Viet (Vietnamese Gods and Man). Nha Xuat Ban Van Hoa Thong Tin, Ha Noi

Thompson S (1958) Motif-index of Folk-literature: A Classification of Narrative Elements in Folktale, Ballads, Myths, Fables, Medieval, Romances, Exempla, and Local Legends, 5rd edn. Indiana University Press, Bloomington

Tran ĐH (1995) Nho giao va van hoc Viet Nam trung can dai (Vietnamese Confucianism and Literature in the Medieval Times). Nha Xuat Ban Van Hoa Thong Tin, Ha Noi

Tran NT (2006) Tim ve ban sac van hoa Viet nam (Vietnamese Cultural Identity). Nha Xuat Ban Thanh Pho Ho Chi Minh, Ha Noi

Tran N et al. (1997a) Tong tap tieu thuyet chu Han Viet Nam (quyen 1) (General Collection of Vietnamese Novels Written in Han characters, vol. 1). Nha Xuat Ban The Gioi, Ha Noi

Tran N et al. (1997b) Tong tap tieu thuyet chu Han Viet nam (quyen 2) (General Collection of Vietnamese Novels Written in Han Characters, vol. 2). Nha Xuat Ban The Gioi, Ha Noi

Tran IN (2000) Nghien cuu so sanh Tien dang tan thoai và Truyen ky man luc (Comparative Study of Tieu Dang Tan Thoai and Truyen ky man luc). Nha Xuat Ban Hoi Nha Van, Ha Noi

Tran NT (2012) Van hoc Viet Nam tu the ky 10 den the ky 19 (Vietnamese Literature from 10th Century to 19th Century). Nha Xuat Ban Giao Duc, Ha Noi

Tran NV (1999) Loai hinh hoc tac gia van hoc: Nha Nho tai tu và van học Viet nam (Type of Literature Author: Confucian and Vietnamese Literature). Nha Xuat Ban dai Hoc Quoc Gia Ha Noi, Ha Noi

Tran TA (2014) Dac trung the loai va viec van ban hoa truyen thuyet dan gian Viet Nam (Characteristics of Genres and the Documentation of Vietnamese Legends. Nha Xuat Ban Khoa Hoc Xa Hoi, Ha Noi

Tran TP (eds) (2017) Linh Nam chich quai (Strange Stories Gathered from Linh Nam Realm). Nha Xuat Ban Van Hoa, Hanoi

Vietnamese Academy of Social Sciences (2004) Tong tap van hoc dan gian nguoi Viet: Truyen co Tich (tap 6) (Collection of Vietnamese Folk Narratives-Fairy Tales. Vol. 6). Nha Xuat Ban Khoa Hoc Xa Hoi, Ha Noi, (vols 19)

Vo NT, Ngo ĐT (1990) Tu bat tu (Four Immortal Gods). Nha Xuat Ban Dan Toc, Ha Noi 
Vu HV (2017) Dao giao va nhung bieu hien trong tin nguong dan gian Viet Nam (Taoism and the Manifestation of Vietnamese Folk Beliefs). Nha Xuat Ban Chinh Tri Quoc Gia, Hà Nội

Valk Ü (2005) Discursive shifts in legends from demonization to fictionalization. Narrat Culture 2:141-165

\section{Acknowledgements}

This research was funded by National Foundation for Science and Technology Development (NAFOSTED) under grant number 602.05-2018.01.

\section{Competing interests}

The authors declare no competing interests.

\section{Additional information}

Correspondence and requests for materials should be addressed to N.T.K.N.

Reprints and permission information is available at http://www.nature.com/reprints
Publisher's note Springer Nature remains neutral with regard to jurisdictional claims in published maps and institutional affiliations.

\section{(C) (1)}

Open Access This article is licensed under a Creative Commons Attribution 4.0 International License, which permits use, sharing, adaptation, distribution and reproduction in any medium or format, as long as you give appropriate credit to the original author(s) and the source, provide a link to the Creative Commons license, and indicate if changes were made. The images or other third party material in this article are included in the article's Creative Commons license, unless indicated otherwise in a credit line to the material. If material is not included in the article's Creative Commons license and your intended use is not permitted by statutory regulation or exceeds the permitted use, you will need to obtain permission directly from the copyright holder. To view a copy of this license, visit http://creativecommons.org/ licenses/by/4.0/.

(C) The Author(s) 2021 